\title{
INFLUENCE OF DEMOGRAPHIC FACTORS ON THE LABOR MARKET IN UKRAINE
}

\author{
Antonina Ignatenko ${ }^{1}$, Tetiana Shapovalova ${ }^{2}$ \\ Lviv Polytechnic National University, Lviv, Ukraine \\ ${ }^{1}$ Student of bachelor program «Social welfare» of Department of Sociology and Social Work \\ ${ }^{2}$ Candidate of Economic Sciences Associate Professor of Department of Sociology and Social Work
}

Background: The current Ukrainian labor market is a rather unstable element of the national economy. All market depends on many factors and different types of macro and microeconomic transformations, globally and nationally. One of the main factors influencing the Ukrainian labor market is demography, mainly its processes, that directly affect different aspects of the functioning of the market.

Purpose: identification of the main factors influencing the modern Ukrainian labor market. This work will separate the demographic processes of influence and determine their importance for economy of Ukraine.

Methods: In this study will be used general scientific methods to describe the state of Ukrainian labor market. One of the main methods will be content analysis, which will help us to understand the demographic situation in the country. Obviously, will be used analysis of scientific articles on relevant topics, statistics approved by the State Statistics Service of Ukraine and combined data provided by the State Employment Center.

Results: Recently, the demographic situation in Ukraine is in a very difficult situation, which has a direct impact on the labor market. Demographic indicators in Ukraine are characterized by population decline, aging of the nation, migration processes, gender gap in employment. These processes complicate the normal functioning of the labor market and slow down the development of the economy.

Conclusion: It is important to understand that the demographic factors affecting the labor market are important factors in shaping the country's sustainable development. Demographic processes occurring at the external and internal levels should shape the state demographic policy. After all, active regulation of this aspect of human life is a possible tool for shaping the sustainable development of the country's economy.

Keywords: labor market, demographic factors, labor force, market economy, labor migration, emigration of labor force, gender gap in employment, growth of natural population, population aging.

Ринок праці є важливою складовою глобальної ринкової економіки. Одною із основних відмінностей даного ринку - це акумуляція не фінансових надходжень, а людськими ресурсами, а саме - робочою силою, в результаті чого створюється обіг фінансових ресурсів. Важливо розуміти, ринок праці в основному залежить тільки від процесів здійсненних за участі робочої сили.

Ринок праці - система відносин, які склалися у суспільстві з приводу купівлі - продажу специфічного товару - «робочої сили». Наразі ринок праці включає також в себе політичні, соціальні та економічні відносини. Саме ці відносини найкраще описують сучасний стан та рівень розвитку ринку праці на даному етапі. Учасниками даних процесів виступають: держава, підприємці та працівники. Основний товар на ринку праці - робоча сила - володіє фізичними та моральними якостями, які використовуються у ході виробничого процесу (Балановська Т.І., Гогуля О.П., Драгнєва Н.I.,2012).

Варто зазначити, що ринок праці, як і будь-який інший, не може існувати без попиту та пропозиції на товар. Саме ці два показники визначають стабільність та розвиток того чи іншого аспекту економіки, яка існує в реаліях ринкової економіки. Вищезазначені основні елементи ринку не є схильними до статичності тому, що на них впливає велика кількість різноманітних чинників.

Серед факторів впливу на ринок праці в Україні можна виділити, так :

1. Природно-географічні - базові чинники, що впливають на зайнятість населення.

До них належать: ресурсний потенціал регіонів, наявність земельних, водних, паливних, енергетичних ресурсів. 
2. Демографічні, тобто чисельність, стать, вік, професійно-кваліфікаційні характеристики населення, природний і механічний рух, зміну частки економічно активного населення в результаті зрушень у рівнях народжуваності і смертності та ін. 3. До економічних факторів, що впливають на зайнятість населення, варто віднести: рівень економічного розвитку держави (ВВП на душу населення); ступінь інвестиційної активності; податково-бюджетну і грошово-кредитну політику держави; рівень інфляції.

4. Соціальні фактори, що охоплюють соціальний захист працездатного населення, систему освіти, культури, охорони здоров'я, а також розвиток особистих здібностей і ділових якостей, професійної майстерності кадрів.

5. До законодавчо-правових факторів, що впливають на зайнятість населення, треба віднести ухвалення та дотримання законодавчих і нормативно-правових актів, що регулюють трудові відносини.

6. Політичні фактори - це рівень політичної стабільності в суспільстві, вектор міжнародної політики держави, міжнародні угоди і зобов'язання, що стосуються зайнятості населення.

7. Організаційні фактори визначають відповідний рівень наукової організації праці, виробництва і управління, організацію діяльності державної служби зайнятості та бірж праці, ступінь інформованості населення про стан ринку праці.

8. Техніко-технологічні фактори передбачають розвиток та впровадження досягнень науки та техніки, технічний прогрес.

9. Історико-культурні фактори враховують усі ментальні особливості населення, традиції, цінності і норми, які склалися в державі та окремих її регіонах і впливають на ступінь зайнятості населення.

10. Екологічні фактори - стан навколишнього середовища та рівень його забруднення; вони впливають на здоров'я населення, на можливість працювати за обраною професією (Куцеволова М.В., 2017).

На нашу думку, відповідно до даної вище класифікації основною рушійною силою впливу на ринок праці в Україні $є$ саме демографічні показники. Спираючись на це твердження важливо виділити, які саме із демографічних чинників прямо чи опосередковано здійснюють даний вплив. До них можна віднести: чисельність населення, статевий розподіл, вікова стратифікація, професійно-кваліфікаційні характеристики населення, природний i механічний рух, рівень міграційних процесів, зміну частки економічно активного населення в результаті зрушень у рівнях народжуваності і смертності та ін.

Останнім часом демографічна ситуація в Україні знаходиться у дуже скрутному становищі, що прямо впливає на ринок праці, адже зменшується обсяг робочої сили, що викликав іiі дефіцит. Демографічні показники в Україні характеризується зменшенням чисельності населення. За останні 20 років цей показник скоротився майже на 8 млн осіб, досягнувши у 2020 році значення 41902,4 тис. осіб (без урахування тимчасово окупованої території Автономної Республіки Крим, м. Севастополь).

Таким чином, до даного дослідження потрібно долучити актуальні статистичні данні. Відповідно до офіційної інформації Державною службою статистики України станом на 2018 рік кількість економічно активного населення складає 17 939,5 тис. осіб. Варто зазначити що даної категорії населення відносять осіб віком від 15 до 70 років. Відсоткова частка такої групи населення складає 72,7 \%. Дійсно, якщо подивитися на числові значення, здається, що ситуація не є такою складною, як могло здатися на перший погляд. Та фактично, свою трудову діяльність в Україні люди починають з 18 до 60 років. Таким чином, відсоткове відношення зменшиться (Куцеволова М.В., 2017).

Ще одним фактором впливу на ринок праці - це проведення антитерористичної операції. Зменшення кількості основного ресурсу відбувається 3 причин як природного скорочення за рахунок збільшення смертності, так і міграції населення. Кількість економічно активного населення за досліджуваний період зменшилася з 25562 до 18098 тис. осіб. Загалом такі ж тенденції властиві і показнику рівня зайнятості населення країни, що доводить значний вплив демографічних факторів на показники розвитку сфери зайнятості населення . 32014 року 
чисельність населення зазначається без урахування тимчасово окупованої території Автономної Республіки Крим, м. Севастополь та частини зони проведення антитерористичної операції (АТО).

Варто зазначити, що на загальну демографічну ситуацію вливає недостатня кількість народжених. Так, станом 2019 показник природного приросту населення в Україні складає -272297. Відповідно, ми можемо спостерігати тенденцію до спаду народжуваності та як результат скорочення чисельності населення країни, адже на одного померлого припадає 0,5 новонародженого. Ця проблема становить загрозу не тільки для ринку праці, а й для економіки країни в цілому. У випадку продовження поглиблення даної тенденції ринок праці може зазнати незворотних змін. Може виникнути так звана «криза робочої сили», адже при зменшенні кількості населення змінюється і обсяг робочої сили, що призведе до дефіциту такого важливого ресурсу.

Притаманною для сучасної української демографічної ситуації є явище старіння нації. Під старінням населення або демографічним старінням, розуміють збільшення частки чисельності літніх людей у демографічній стратифікаційній системі. Старіння населення є наслідком тривалих демографічних змін у характері відновлення населення, народжуваності і смертності та їхньому співвідношенні, також частково міграційні процеси. Відповідно до даних Державною службою статистики України у 2015 році людей віком від 60 і старше було 9330 430, то станом на 1 січня 2018 року кількість такої групи населення становить 9679745 осіб. Отже, кількість людей літнього віку збільшилась на 349315 осіб, а у відсотковому еквіваленті цей показник складає 3,7\%.

Також, важливо окреслити, що демографічне старіння може спровокувати не тільки частки трудоактивного населення (а відтак - формування з часом певного дефіциту робочої сили), але й збільшення демоекономічного навантаження на працездатне населення, що викличе у свою чергу скорочення фінансових можливостей для соціального забезпечення в умовах загального зростання попиту на соціальні послуги з боку осіб літнього віку, самотніх, малозабезпечених. В Україні останніми роками навантаження на працездатний за віком контингент повільно, але неухильно збільшувалося переважно за рахунок осіб, старших за працездатний вік. Тому для відносної стабілізації соціально-економічного стану було застосовані такі інструменти, як: підвищення пенсійний віку та зростання податків. Наслідками такого перенавантаження - швидке вироблення робочого потенціалу людини та погіршення здоров'я, втрата працездатності. Темпи зростання кількості людей з інвалідністю в Україні залишаються високими, а середній вік серцево-судинних захворювань наближається до 40 років(Романуха О.М., 2016).

На нашу думку, одним із основних чинників, які впливають на демографічну ситуацію країні, в контексті розгляду ринку праці - міграційні процеси зовні та всередині України. У контексті даної роботи ми будемо використовувати саме поняття трудової міграції - це переміщення працездатного населення з одних держав до інших з метою працевлаштування строком більше ніж на рік, що викликається причинами економічного характеру. Адже трудова міграція як економічне явище $є$ одним із факторів формування суспільства, що безпосередньо впливає на його становлення та функціонування. Сьогодні трудова міграція стала одним з головних чинників соціально-економічних трансформацій і розвитку всіх регіонів України(Бербенець О. В., 2014).

За даними представництва ООН в Україні, кожен п'ятий українець є потенційним мігрантом і хотів би виїхати 3 населеного пункту, в якому живе. При цьому 3 тих, хто вирішив їхати, близько 15 \% зробили свій вибір на користь іншої місцевості в Україні і лише 5 \% мають намір виїхати за межі держави. Якщо звернутися до актуальних статистичних даних ми можемо побачити, що для більшості регіонів є характерною від'ємна внутрішня міграція. Так, у 2019 позитивний приріст внутрішньої міграції спостерігався лише в 7 областях: Івано-Франківській, Київській, Львівській, Одеській, Полтавській, Харківській та Чернівецькій. Таким чином, у всіх інших областях показник попиту на робочу силу є вищим ніж у вищезгаданих областях. Розглядаючи ринок праці на регіональних рівня можна зробити висновок, що він є досить деформованим та не рівномірним.

Сильного впливу зазнає українська економіка в результаті поширення еміграції трудової сили. Дане явище в Україні отримало друге дихання після обставин 2014-2015 років. Станом на 2019 рік, за даними Міністерства соціальної політики на постійній основі за кордоном 
працює 3.2 млн українців, а в окремий період - від 7 до 9 млн осіб. Дані процеси пов'язанні і нестабільністю внутрішніх процесів та глобалізацію більшості сфер життя людини. Це явище впливає не тільки погіршення української економіки, але деколи становить загрозу для економік інших країн світу. Адже, поки Україна знайомиться із кризою трудових ресурсів у деяких галузях, інші країни, за допомогою наших громадян, зазнають дефіцит пропозиції на даний ресурс. Найпопулярнішими країнами для українців в контексті трудової еміграції $\epsilon$ Польща, Італія, Іспанія, Росія та Німеччина.

Останнім у даній статті демографічним параметром впливу на ринок праці $є$ гендерний розрив зайнятості населення, який з час не зменшується. Така ситуація зумовлена дією ринкового конкурентного механізму та наявністю прямих бар'єрів для зайнятості (вужчий професійний вибір, відсутність необхідних робочих місць або необхідної кваліфікації, вихід у декретні відпустки). Жіноча зайнятість традиційно переважає у сферах діяльності з найнижчими рівнями середньої заробітної плати - сфері соціального забезпечення, освіті, охороні здоров'я, побутовому обслуговуванні та культурі, в яких жінки становлять понад 70 \% працівників.

Окресливши усі вищезгадані демографічні явища, які впливають на ринок праці, ми розуміємо, що для ефективного регулювання даної сфери людського життя потрібна специфічна державна політика. Саме результативна державна демографічна політика допоможе регулювати стан ринку праці. Для цього потрібно запровадити ряд заходів, котрі будуть стабілізувати такі демографічні явища, як: народжуваність, рівень природного приросту населення, рівень міграції та еміграції, показники гендерного розриву зайнятого населення. За допомогою реалізації даних заходів можна досягти стабільності на ринку праці та зробити ще один крок на зустріч до сталого розвитку.

\section{Список використаних джерел}

Балановська Т.І., \& Гогуля О.П., \& Драгнєва Н.I. (2012). Ринок праці: реалії та перспективи. Retrieved from http://stp.diit.edu.ua/public/journals/69/Vymohydotrans.pdf

Куцеволова М.В. (2017). Фактори впливу на зайнятість населення регіонів: можливості використання при формуванні політики зайнятості. Демографія та соціальна економіка, 11, 225-236. Retrieved from file:///D:/Downloads/dse 20172 2 19.pdf

Романуха O.M. (2016). Соціально-економічні наслідки старіння населення України. Науковий вісник Херсонського державного університету, 17, 91-94. Retrieved from http://www.ej.kherson.ua/journal/economic_17/3/25.pdf

Бербенець О. В. (2014). Вплив трудової міграції населення України на розвиток ринку праці. Ефективна економіка, 2. Retrieved from http://www.economy.nayka.com.ua/?op=1\&z=4449

\section{References}

Balanovskaya TI, \& Gogula OP, \& Dragnev NI (2012). Labor market: realities and prospects. Retrieved from http://stp.diit.edu.ua/public/journals/69/Vymohydotrans.pdf

Kutsevolova MV (2017). Factors affecting the employment of the population of the regions: opportunities for use in formulating employment policies. Demography and Social Economics, 11, 225-236. Retrieved from file:///D:/Downloads/dse 2017_2_19.pdf

Romanukh OM (2016). Socio-economic consequences of population aging in Ukraine. Kherson State University Scientific Bulletin, 17, 91-94. Retrieved from http://www.ej.kherson.ua/journal/economic 17/3/25.pdf

Burbenets O. W. (2014). Impact of labor migration of the Ukrainian population on the development of the labor market. An efficient economy, 2. Retrieved from http://www.economy.nayka.com.ua/?op=1\&z=4449

\section{Контактна інформація:}

Antonina Ignatenko

tonya.ignatenko6@gmail.com

Shapovalova Tetiana

gg39358@gmail.com 